\title{
PECULIARITIES OF INSTITUTIONALIZATION OF THE TRANSDANUBIAN AND THE DANUBE COSSACKS ACCORDING TO THE MATERIALS OF SPHRAGISTICS, VEXILLOLOGY AND SPATIAL LOCALIZATION
}

\section{Olena Bachynska}

ORCID: https://orcid.org/0000-0003-0496-5742

DSc (History), Professor

Odesa Illya Mechnikov National University

2, Dvoryanska Str., Odessa, 65082, Ukraine

Olena_an@ukr.net

The importance of symbols of power, such as seals, bunchuks or flags, can hardly be overestimated. Their appearance in one or another form testifies the legalization of a certain organization, institution, community. That is why the proposed article is devoted to the peculiarities of this process, of the process of institutionalization at the Transdanubian Cossacks and Danube Cossacks during the last quarter of XVIII $X I X$ centuries.

It is suggested to consider this processes through materials of sphragistics, vexillology and spatial localization, such as seals, bunchuks, flags, etc. It was found that the emergence of these symbols of power first reflected the legalization and integration into a certain state system of the certain Cossack institution-Sich or the army. Secondly, in each of these institutions, the seals and flags displayed symbols of the corresponding state - the Ottoman or Russian Empire, sometimes with respect for the Cossack past. For example, it should be remembered combining the symbols of Islam with Christianity in the flags of the Transdanubian Cossacks, or providing the incisions (maces) to the Danube Cossacks in Russia. All these symbols kept for the Cossacks their traditions of life and respect to their glory.

Key words: Transdanubian Sich, Danube Cossack army, seal, bunchuk, bajrak, flag, Katyrlez village, Dunavets village, stanitsa (village).

Олена Бачинсъка

ORCID: https://orcid.org/0000-0003-0496-5742 Доктор історичних наук, профессор, зав. кафедри історії України Одеський національний університет імені I. I. Мечникова, Вул. Дворянсъка, 2, 65082, Одеса, Україна Olena_an@ukr.net

\section{ОСОБАИВОСТІ ІНСТИТУААІЗАЦІЇ ЗАДУНАЙСЫКИХ ЗАПОРОЖЦІВ ТА ДУНАЙСЬКИХ КОЗАКІВ ЗА МАТЕРІАААМИ СФРАГІСТИКИ, ВЕКСИАОАОГIÏ ТА ПРОСТОРОВОЇ АОКАМІЗАЦІЇ}

Стаття присвячена особливостям проиесів інституалізаиї у задунайців та дунайсъких козаків протягом останнъої чверті XVIII - XIX cm. 
Запропоновано розглянути иі проиеси за допомогою матеріалів сфрагістики, вексилології та просторової локалізації, зокрема печатки, бунчуки, прапори тощо. З'ясовано, що поява иих символів влади, по-перше, відображала легалізаиію та вписування у відповідну державну систему певну козацьку інституиію - Січ або військо. По-друге, в кожній з иих інституиій на печатках і прапорах відбивались символи відповідної держави - Османської або Російської імперії, інколи з повагою до козащького минулого. Як, наприклад, поєднання ісламських $і$ християнських символів на прапорах задунайиів, або надання насеки (булави) дунайським козакам в Росії.

ключові слова: Задунайська Січ, Дунайське козащьке військо, печатка, бунчук, байрак, прапор, с. Катирлез, с. Дунавець, станиия.

Важливість символів влади, а саме печатки, бунчуки або прапори, важко переоцінити. Їхня поява в тій чи іншій формі свідчить про цегалізацію певної організації, установи, громади. Саме тому запропонована стаття присвячена особливостям цього процесу, процесу інституалізації у задунайських запорожців та дунайських козаків протягом останньої чверті XVIII - XIX ст.

Завершення існування Наддніпрянської Січі у 1775 р. привело до переходу на територію Османської держави значної кількості запорожців. Спочатку вони оселились у межах Очаківської округи, Дністра та пониззя Дунаю. Зазначені землі були обрані запорожцями не випадково, адже у другій половині XVIII ст. ці території Османської імперії найбільше відповідали умовам степового кордону звичного дмя запорожців і стали районами, де можна було б відновити традиційне господарство та власну втрачену організацію - Січ. Протягом 1770-80-х років є декілька повідомлень про звернення козаків отримати мегальну організацію, які вони направляли до султана та константинопольського патріарха, і у вересні 1778 р. російський полковник П. Репнинський повідомляв про те, що османська влада має намір створити на Дністрі Січ, для чого “місце визначене між Бендерами й Аккерманом", козакам надавались озброєння та коні. Проте внаслідок різних обставин до реального заснування Січі саме на цій території справа не дійшла. Ймовірно вже 3 середини 80-x pp. XVIII ст. вона знаходилась у с. Катирлез в гирлі Дунаю (тепер с. Сфинту Георге (Sfintu Gheorghe) у повіті Тульча (Румунія)). Більшість колишніх козаків, незадоволених своїм становищем у російських, молдавських, австрійських землях, почали стягуватись навколо Катирлезької Задунайської Січі. Факти свідчать про важливість існування Катирлезу для задунайських запорожців, як традиційного козацького центру. Однак про дану Січ відомо досить мало через брак джерел, тому розглянемо наявну інформацію для визначення їі ролі та статусу, як для самих козаків, так і для османського уряду.

На території Січі традиційно знаходимась площа з церквою, курені (житла козаків), приміщення для запасів їжі, зброї тощо. Військові підрозділи козаків формувались за куренями, але в разі необхідності вони приєднувались групами до османських частин. Деякі документи дозволяють припустити, що територією, 3 якої збирали податки на 
утримання козаків була Волощина (Eflak voyvodas1). На Січі, за усталеною традицією проживало керівництво - кошовий отаман, старшина, куренні отамани і цише неодружені козаки. Одружені мали жити в селах і хуторах навколо Січі. Січ підпорядковувалась османським керівникам у Сілістрії, Тульчі або Браїлі. Враховуючи особливості перебування Січі на землях Османської держави, козаки отримали назву в османських документах "Potkalı/Butkalı Kazaklar1", яка відрізняла іх від інших українських гетьманських козаків - "барабашів", а також від російських донських козаків-некрасівців - "Ignat Kazaklar1". Зауважимо, що ставлення російської влади до запорожців теж відбилось в їхній назві - в російських документах вони фігурують, як “невірні" турецькі або запорожці з-за Дунаю, в історичній мітературі вони отримали назву “задунайські запорожці” або “задунайці”.

Як і в кожній Наддніпрянській Січі, в Задунайській Січі старшина мала клейноди, ймовірно, що їх надав султан Абдул-Гамід I разом 3 дозволом на заснування Січі. В даному випадку символи вцади мали свою специфіку через перебування в межах в Османської держави, що відбилось у сфрагістиці та вексилології. Серед клейнодів Катирлезької Задунайської Січі важливу роль відігравала печатка, що відома вже 3 90-х років XVIII ст. Iї поява безперечно засвідчує визначений статус козаків. Так, російський купець Є.Кцьонов, який перебував на Січі у січні 1796 р., просив у отамана Якима Гардового “п'ять планкетів 3 військовою печаткою для проїзду за кордон козаків". Печатка не мала

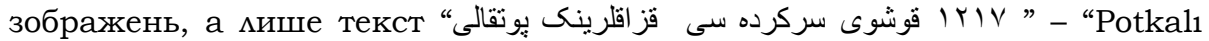
kazaklarının ser-kerdesi koşovıy. 1217" - "Поткальських козаків отаман кошовий. 1802/1803". (див. додатки, рис. 1). Більш точно встановити дату на відбитку проблематично, адже 1217 рік Хіджри - розпочався 04.V.1802 p. і закінчився 22.IV.1803 р. Печатка задунайців цього періоду є і під текстом білета, що виданий й іншим кошовим отаманом: “Остап Міняйло, середній на зріст, у цьому квитку, зазначений, $\epsilon$ Путкальських козаків з Херделезької проливи (гирла). Коли буде по кріпостях та містах, де є начальники, хай ніхто не бере $з$ нього податків і ніхто йому не наказує. 1221 року, місяця Мухарема 28 дня ${ }^{3}$. Кошовий Бахмут. Драгоман Осман. Печатка Коша" [2, с. 126-127].

Відомі й інші клейноди задунайської старшини в цей період - бунчук та прапор. Свідчення про наявність прапора $\epsilon$, хоча й не зовсім коректна, одного 3 задунайських запорожців: “Знамя действительно было при запорожских казаках и один пернач, но было ми то знамя от кого пожаловано [...] кошевой сам сдемал ему неизвестно, знамя было величиной как у турок, цвету желтого и такого же и [..мо], а на середине было белого цвета полумесяц" (подано мовою оригіналу - О.Б.). Про наявність в Катирлезькій Січі прапора пише й згаданий вже купець Є. Кльонов, який їздив до задунайців щоб “весь Кіш, бунчуки, знамена і церкву перевести до Pociï” [2, c. 112, 126-127].

328 мухарема/ мухаррама 1221 року Хіджри $=17$ квітня 1806 р. 
Важливим фактом, що свідчить про статус Катирлезької Січі $є$ наявність одружених козаків і народжених на землях Січі дітей. Так, протягом 1789-1794 рр. в Катирлезі народилися від батьків запорожців Степан Чумак, Петро Чернега, Василь Чумак, Іван Кучеренко; близько 1799 р. в “запорозькому селищі Рая на урочищі Катирлез” незаконно від “дівки сербської Євдокії" народився Трохим Сербиненко і був взятий на виховання запорожцем Герасимом Похимою у Вишестебнівський курінь, близько 1786 р. у Сейменах від “тамошнього" запорожця Афанасія та матері Софії народився запорожець Гаврило Білий, а його дружина Авдот'я Концева народимась у Катирлезі близько 1800 р. від “тамошнього” запорожця Кук'яна і матері Ірини [5, оп.190, спр.13 (1824), арк. 6-9 зв., 124, 250-250 зв., 341 зв.]. Значна кількість козаків народимась і в інших селищах і містах Добруджі - Монастирищі, Іглиці, Райї, Беш-тепє, Сарнусах, Туркоях, Сомовому, Торговиці, в Старій Кілії, Бабадазі, Каралашах. Це зайвий раз засвідчує, що козаки вважали більшість територій в гирлі Дунаю своїми, і проживали у різних населених пунктах по узбережжю навколо Січі.

Активна розбудова Катирлезької Січі задунайцями і пов'язаний 3 нею перерозподіц земель, як засіб існування, мав неодмінно призвести до конфмікту з некрасівцями (донськими козаками старовірами). У суперечках між двома групами козаків першого значення мала вигідна земля у дунайському гирлі і рибні цови, а потім їні різні релігійні традиції. Впливала на стосунки між запорожцями і некрасівцями й кризова ситуація в середині османських володінь 1780-х - початку XIX ст., пов'язана з реформаторською діяльністю султана Селіма III та великого візира Алемдара Мустафи паші (Байрактара) в управлінні, економіці, армії. Серед противників реформ в Ізмаї^і був Ібрагім Пеглеван, за призвіськом Баба-паша. В середині 1806 рр. некрасівці в складі військ Пеглевана здійснили напад на Катирлез, спалили житла козаків і багатьох порубали. Задунайці перебрались на чолі з кошовим Гнатом Ковалем до Браїли під захист назиря Ахмет-паші [2, с. 109].

Під час нової російсько-турецької війни, що розпочалась в кінці 1806 р., разом 3 кошовим отаманом у Браїлі знаходилась старшина, зокрема, писар Данило Білий і духівництво. Можна припустити, що в Браїлі знаходився задунайський Кіш, а Катирлез продовжував залишатися центром задунайців, хоча і не був відновмений як Січ через війну.

Щоб залучити задунайських запорожців на свій бік, командуючий російською Молдавською армією І. Міхельсон і новоросійський генералгубернатор Е. де Рішельє запроектували створити на Дунаї козацьке військо, “дати йому найменування Усть-Дунайського, подаючи надії, що воно може одержати приклад Війська Запорозького, якщо як чорноморці, це заслужить". 18 січня 1807 р. I. Міхельсон зробив оголошення, в якому від імені російського уряду звертався до задунайських запорожців з закликом вступити до Усть-Дунайського Буджацького козацького війська. Центрами його формування призначалися Кілія і Галац. 
Створенням Усть-Дунайського Буджацького війська російська адміністрація передбачала взяти під свій контроль місцеве українське населення, одержати додатковий військовий контингент i, спираючись на нього, завдати рішучого удару задунайському козацтву. Устрій війська нагадував Запорозьке. Управління здійснював Кіш на чолі 3 кошовим отаманом. Старшина носила традиційні найменування. Військо складалося з куренів на чолі з курінними отаманами. Кошовому отаману надавався пернач, а війську - прапор і військова печатка. На печатці зображалось: у центрі - у вигляді дуги річка Дунай, над дугою хрест та сонце, під дугою домовина на півмісяці (див. додатки, рис. 3) [5, оп. 214, спр.11 (1825), арк. 260]. Прапори планували зробити за зразком Бузького козацького війська [5, оп. 218, спр.1 (1806), арк. 46 зв., 54]. На цьому, власне, і закінчувалась подібність між УстьДунайським Буджацьким і Запорозьким військами. Різниці між ними були мали принциповий характер. Військо цілком і повністю підлягало російському командуванню. Нагляд за ним здійснювався начальником Галацького військового загону генерал-майором П. Колюбакіним. Кошовий отаман і вся інша старшина призначалася царською адміністрацією, а не обиралася козаками. Так, першим кошовим отаманом було призначено єлизаветградського поміщика Івана Підмесецького, другим став, виходець з чиновницьких кіл, Фома Бучинський [2, с. 112-113]. За висловом нового головнокомандуючого Молдавською армією О. Прозоровського, особи, які записувались до усть-дунайців, “бажали перейти в цю "Нову Січ", щоб користуватися бімьшою волею і створити там збіговисько, подібне до того, що колись на Дніпрі було" (тобто Запорозьку Січ - О. Б.). Питання про це розглядалося на засіданні Комітету міністрів, де підкреслювалося, що втечі “особливо збільшилися після проголошення в 1807 р. про вільний вступ до Буджацького запорозького війська". 20 мипня 1807 р. Олександр I в рескрипті на ім'я I. Міхельсона видав наказ припинити подальше формування війська і вжити всіх заходів щодо повернення утікачів. Однак, не зважаючи на всі спроби повернути усть-дунайців, в більшості, вони знов перейшли до задунайських козаків.

Після завершення російсько-турецької війни 1806-1812 рр. територія звична дмя традиційного життя козаків ще більше звужується. За Бухарестським миром 1812 р. кордон проходив по Кілійському гирлу Дунаю; у 1817 р., після спеціальної угоди з Портою - по Сулинському, острови $\Lambda$ еті та Четал ставали нейтральною зоною, звідки мали виселити всіх запорозьких рибалок до Сулинського гирла, де не було для них зручних місць для рибного мову і відомих торговельних міст, таких як Ізмаїл і Кілія. Внаслідок цього задунайські запорожці вирушили на некрасівські поселення і зайняли їх головний центр - с. Верхній Дунавець на Георгіївському гирлі, там де і заклали Січ (тепер с. Верхній Дунавець (Dunavățu de Sus) в повіті Тульча (Румунія). Об’єднуючим центром іiі стали “старі" запорозькі січовики, які прагнули зберегти традиції і право, виконували розпорядження турецької адміністрації та становили основний військовий контингент Січі. Окрім них велику 
групу задунайців скмадали рибалки. Вони визнавали владу кошової старшини i, таким чином, отримували певний козацький статус в межах Османської держави. Біля Дунавецької Січі розташовувалися селища, де

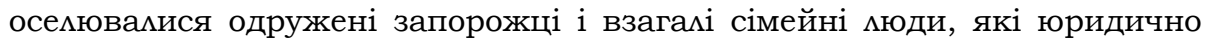
не належали до козацтва. Насемення в них продовжувало зватися райя, як і все християнське населення Османської імперії, яке сплачувало податки. Тому і населені пункти в Січі звалися запорозькою або козацькою райєю. До неї входими селища - Райя (Козацька), Караорман, Саранасув, Катирлез (Сфинту Гєоргє), Озаклія, Ігмица, Нижній Дунавець, Горга, Муругіль та інші [2, с. 130]. На самій Січі знаходимись курені, титарня, де розміщувався духовний причт і паланка, в якій знаходились помешкання кошового, комори, канцелярія, погріб. В куренях жили неодружені козаки від двох до п'яти осіб, а інші знаходимись на заробітках або в походах.

Всю адміністративну, судову, військову вмаду і деякі господарські обов'язки виконувала старшина. Вона, як і в Запорозькій і Наддіпрянській Січі була виборною. До старшини входими кошовий отаман, писар, осавул, драгоман (перекладач). Можна припустити, що писар i осавуц допомагали кошовому в управлінні. 3 турецькими чиновниками кошовий мав вести переговори мише через драгомана. Кошовий розмовляв виключно українською мовою, навіть, якщо б і знав турецьку. При кошовій старшині знаходився турецький спеціальний “повірений у справах" або драгоман дмя повідомлення про рішення турецького уряду, нагляду за політичною ситуацією в Січі та збору податків (харачу), якщо задунайці займались господарством за межами козацької території. Драгоман та писар також веми мистування, видавали білети козакам дмя виїзду на промисли. За деякими даними в останні роки Січі драгоманом був тульчинський аян Гусейн-Ефенді, який мише зачитував фірмани і ставив запорожцям візи на білетах 3 чого мав гарний прибуток [2, с.132]. Кошовий отаман був під наглядом у сілістринського або тульчинського паші, останній навіть одержав звання козак-баші. Одним 3 таких був двобунчужний тульчинський паша Юнус. Зокрема він повідомляв російське керівництво, про те, що козаки можуть виходити з Січі займатися рибальством або торгівлею, вони обов'язково мають отримати паспорт 3 його печаткою, або пропуск від кошового отамана, в той самий час паша просив повідомляти про тих, хто виходить із Дунавця без дозволу [3, с. 96].

Клейноди скмадами бунчук, пернач, топуз, печатка та байрак. Всі вони мали зберігатися в церкві. За турецьким регламентом кошовий отаман мав звання “двутульний паша", про що свідчать підписані отаманами документи (див. додатки, рис. 2). У вітчизняній мітературі більш вживаним $€$ термін “двобунчужний” [5, оп. 214, спр. 11 (1816), арк. 150]. Бунчук є трансформованим слов'янським еквівалентом турецького символу влади Туг. Бунчук являв собою держак з навершієм у вигляді кінського волосся. Кількість бунчуків (кількість пасм кінського волосся) визначала посаду, наприклад, два бунчука міг мати керівник провінційного уряду або окремої фортеці. 
Топуз (тур. topuz) явмяв собою бойову булаву, саме з такою назвою бумава відома при церемоніях у молдавських господарів [6, с. 216], болгарській та угорській традиціях. $€$ версії, що цим клейнодом $€$ інкрустована дорогоцінними каміннями золота шабля або кинджал, однак це менш вірогідно [4, с. 8].

В дослідженнях відомого дослідника Ф. Вовка, на основі свідчень задунайського козака Ананія Коломійця у 80-х роках XIX ст. визначено, що задунайські козаки "взагалі не мали січового прапора", "він замінювався у них турецьким бунчуком.... кожний курінь задунайців мав свій байрак - рід значка з червоного сукна з білим півмісяцем та 6 зірками. У випадку смерті будь-кого 3 козаків, перед куренем виставлявся цей байрак як військова почесть померлому” [2, с. 126]. Про наявність невеликого прапору (штандарту) - значка - у кожного куреня, зазначав А. Скальковський, за нього відповідав курінний хорунжий або значковий товариш. В той самий час у Д. Яворницького є згадка про те, що під час переходу козаків в межі Росії у 1828 р. в них з собою було “двадцять курінних прапорів із простими дерев'яними держалами”, що мали зберігатися у Преображенському соборі у Санкт-Петербурзі [11, с. 172]. На основі свідчень А. Коломійця, Ф. Вовк пояснює відсутність прапора невідповідністю християнських емблем на прапорах колишнього Війська Запорозького і з тим, що задунайські запорожці перебували під владою мусульманської країни [2, с. 126]. Саме це і не відповідає дійсності, як свідчать документи. За думкою, відомого історика Я. Дашкевича, Османська держава надавала кошовим отаманам Задунайської Січі байрак, що явмяв собою прапор всього Коша та окремих козацьких частин. Такий прапор мав поєднувати символи ісламу та християнського світу (у візантійський традиції) [4, с. 9-10]. На цьому акцентує увагу й болгарський історик І.Стойчев, який пише про таку традицію для всіх християнських підрозділів, що служили в Османській імперії. Спираючись на мемуари М. Чайковського (Садик паші) можна припустити, що прапор Задунайської Січі складався з двох частин: на одній частині - срібній (білій) був вишитий “православний хрест", на другій - червоній - “османський місяць” [9, с. 4-5]. Зазначений прапор задунайські частини, які у 1828 р. не перейшли до Російської імперії, передали у Стамбулі до патріаршої різниці. Саме його, згодом патріарх освятив і передав М. Чайковському у 1853 р. дмя організованого ним козацького полку. Чи був цей прапор наданий ще у $1778 \mathrm{p}$. султаном Абдул-Гамідом I залишається не з'ясованим. Зображення та опис цього прапору надав зять М. Чайковського, П. Суходольський у своїх спогадах, в них він згадує вперше на двокольоровому прапорі “місяць з зіркою” (див. додатки, рис. 4) [8, с. 371; 9, с.6]. До нього про "місяць з зіркою" на прапорі згадувався на однокольоровому прапорі другого полку М. Чайковського, що формувався пізніше і не був пов'язаний з запорозькою традицією [9, с. 108]. Зауважимо, що Я. Дашкевич надає дискусії про прапор задунайських козаків ще одного важливого моменту, пропонуючи вести традицію цього прапора від гетьманів П. Дорошенка або І. Мазепи [4, с. 10-11]. Однак, це потребує подальших 
документальних пошуків.

У середині 20-х pp. XIX ст. із Задунайської Січі почався масовий вихід козаків у російські межі, що було викликане спробами Османської імперії використати задунайців дмя придушення національновизвольного руху в Сербії та Греції. Врешті-решт на початку нової російсько-турецької війни 1828-1829 рр. султанський уряд оголосив мобілізацію козаків і вимагав їх передислокації до Сілістрії. Частина задунайців була мобілізована в турецьку армію. Здебільшого це були козаки, які дотримувались протурецьких настроїв. Після того кошовий отаман Й. ГАадкий повернувся на Січ і в травні 1828 р. перевів іншу частину козаків через Дунай до російської армії. Подія, що сталася, поклала край існуванню Задунайської Січі.

Слід зауважити, що виходи окремих груп задунайців відбувались і раніше. Так, одна така група одержала землю в Ізмаїльському повіті, де разом з усть-дунайцями в 1818 р. оселилася у селі Дракуля (тепер Трудове Кілійського району Одеської області) [1, с. 11]. У 1820 р. інша група задунайських запорожців й усть-дунайських козаків, незважаючи на опір земській поліції, оселимась в Аккерманському повіті, заснувавши село Акмангіт. Серед тих, хто оселився, були колишні задунайські старшини - полковий осавум Роман Согутчевський. Саме він став організатором виходу частини козаків із Січі. Для засвідчення, виданих ним козакам документів, Р. Согутчевський мав власну печатку, як ознаку законності своєї влади. Це свідчило, що окремої організації козаки ще не мали. На цій печатці позначались його ініціали (див. додатки, рис. 5) [5, оп. 214, спр.11 (1825), арк. 169]. В подальшому козаки Акмангіту використовували печатку громади. Вона мала козацьку традицію, адже на ній зображали козака зі списом (див. додатки, рис. 6) [5, оп. 214, спр. 11 (1825), арк. 260]. Дотримання козацьких традицій проявимось не мише в печатці. Так, в Акмангіті, ще до побудови церкви, задунайські запорожці, обрали в 1820 р. священиком Івана Бобиря, який раніше був в “армійському духовенстві” [1, с. 187].

Новопоселенці сіл Дракуля й Акмангіт уперто відмовлялися від сплати податків і виконання повинностей, рішуче домагаючись відновлення в Південній Бессарабії козацького війська. За їх проектом його територія мала охоплювати землі між Дунаєм та Дністром. Кіш та Січ розташовувались у селі Акмангіт. Козаки вимагали виключних прав на землекористування і рибальство, утворення власних органів самоврядування. За ці пільги військо мало нести на власному кошті прикордонну службу на Дунаї і Чорноморському узбережжі на зразок Чорноморського козацького війська. Підставою для створення війська, за їх відомостями, мав бути перехід до Росії 1200 задунайських запорожців і 200 колишніх усть-дунайських козаків. Саме через те, що акмангітці протягом 20-х років XIX ст. наполегливо домагалися відновмення козацького війська, село стало тим центром у Бессарабії, куди продовжували виходити задунайські запорожці. В тогочасних документтах вони одержали назву акмангітських або мангітських козаків, яка так і увійшла в історичну мітературу. Вже під час нової російсько- 
турецької війни 1828 р. вони черговий раз подали пропозиції щодо відновлення козацького війська, i у червні 1828 р. за допомогою начальника Бабадазької області генерал-майора С. Тучкова вони отримали дозвіл на формування двох Дунайських п'ятисотенних полків. Зараховувати до війська можна було мише тих зазначених козаків i волонтерів з греків, сербів, болгар, албанців, молдаван, волохів (служили в добровольчих частинах російської армії), які оселимись в краї до початку російсько-турецької війни 1828-1829 рр. Після завершення воєнних дій Дунайські полки отримали назву Дунайського війська, яке розмістилося в Аккерманському повіті Південної Бессарабії. Воно складалась 311 станиць і хуторів: Акмангіт, Старокозачя, Волонтирівка, Петрівка, Михайлівка, Миколаївка, Ново-Троїцька, Костянтинівка, Фараонівка, Каїри, Миколаївка-Новоросійська (тепер у Саратському, Білгород-Дністровському, Кілійському, Татарбунарському районах Одеської області та районі Штефан Воде Республіки Момдова). Дия внутрішнього цивільного та господарського управління у війську запроваджувалась Військове Правління на чолі з наказним отаманом. Дия підтвердження законності своєї вцади наказні отамани, Військове Правціння, керівництво кожної станиці одержували уніфіковані з іншими козацькими військами печатки. Як свідчить зображення, вони мали досить простий вигляд: зверху герб Російської імперії, під ним напис «Печ: Дунайского казачьего войска Атмангитской станицы" ("... Волонтировской станицы"; ".... станицы Фараоновка" тощо) (див. додатки, рис. 7). Печатки мали й церкви війська. Після перейменування війська 3 Дунайського на Новоросійське у 1856 р. відповідно змінився напис і на печатках.

На відміну від інших іррегулярних військ в станицях Дунайського війська була ще й насека (булава). Остання була запозичена “зі старовинних козацьких звичаїв, і тепер вводимася як знак, що зобов'язував мюдей поважати суд і порядок" - зазначалось в примітках до “Поможення про Дунайське козацьке військо” [2, с. 48]. Окремих штандартів у війську не існувало до 1856 р. У зв'язку з тим, що дунайські козаки проявими себе, як найкраще, у Кримській (Східній) війні 18531856 рр., за мужність та героїзм вони буми нагороджені штандартами “За хоробрість”, а також отримали права та привілеї армії, а полк № 2 отримав посади сурмачів. Крім цих прапорів кожна сотня отримала сотенні значки (махі штандарти), що були як і насеки “запозичені зі стародавнього козацького звичаю”, й образи Святих Угодників. Як саме вигцядав прапор Дунайського війська не має відповідних описів, але зберіглись зображення козаків з прапорами (див. додатки, рис. 8). Після Аіквідації козацького війська у 1868 р. прапори та інші клейноди зберігались у церкві с. Волонтирівка, подамьша доля їх невідома (в Ізмаїцьському історико-краєзнавчому музею зберігається експонат, що відзначений у виставці, як "Булава Усть-Дунайського Буджацького козацького війська", що за нашим припущенням може бути насекою Дунайського війська).

Таким чином, особливості інституалізації козаків в Османській та Російській імперіях відображалися в сфрагістиці, вексимології та 
просторовій мокалізації. Поява клейнодів у задунайців та дунайських козаків, по-перше, відображала їхню мегалізацію та вписування у певну державну систему. По-друге, в кожній з організацій козаків (Січ або козацьке військо) на печатках і прапорах відбивались символи відповідної держави, інколи 3 повагою до козацького минулого. Це проявлялось в назвах (топуз, пернач, байрак), або, наприклад, поєднання символів ісламу 3 християнськими на прапорах задунайців, або надання насеки (булави) дунайським козакам. Всі ці символи зберігали для козаків їхні традиції життя і повагу до своєї слави.

\section{Джерема та мітература:}

1. Бачинська О.А. Дунайське козацьке військо. 1828-1868 pр. (До 170-річчя заснування). - Одеса: Астропринт, 1998. - 232 с.

2. Бачинська О. Козацтво в "післякозацьку добу" української історії (кінець XVIII - XIX ст.) /Олена Бачинська. - Одеса: “Астропринт”, 2009. - 256 с.

3. Бачинська О.А. Козацьке порубіжжя у Великій політиці між двома російсько-турецькими війнами першої третини XIX ст.// Чорноморська минувшина. Записки Відділу історії козацтва на Півдні України Науководослідного інституту козацтва Інституту історії України НАН України: Зб. наук. пр. - Одеса, 2018. - Вип. 13. - С. 161-194.

4. Дашкевич Я. Прапори задуйських запорожців (XVIII - XIX ст.) //Знак. Число 46, грудень 2008. - С. 8 - 11.

5. Державний архів Одеської області. - Ф.1. - Оп.190. - Спр.13 (1824); Оп. 214. - Спр. 11 (1825); Оп. 214. - Спр. 11 91816).

6. Кантемир Д. Описание Молдавии: факсимиме, матинский текст, русский перевод Стурдзовского списка. - СПб., 2011. - С. 216 [Електронний ресурс]. Режим доступу: https://books.google.com.ua/books?id=G05TDwAAQBAJ\&pg=PA2168lpg =PA216 $8 \mathrm{dq}=\% \mathrm{D} 1 \% 82 \% \mathrm{D} 0 \% \mathrm{BE} \% \mathrm{D} 0 \% \mathrm{BF} \% \mathrm{D} 1 \% 83 \% \mathrm{D} 0 \% \mathrm{~B} 7+\% \mathrm{D} 0 \% \mathrm{~B} 1 \% \mathrm{D} 0 \% \mathrm{BE} \% \mathrm{D} 0 \% \mathrm{~B} 5 \% \mathrm{D0} \%$ B2\%D0\%B0\%D1\%8F+\%D0\%B1\%D1\%83\%D0\%BB\%D0\%BO\%D0\%B2\%D0\%B0\&source=bl\&ots=e Y3eyXMaVE\&ssig=ACUU3U2ugiKo8kEAxXOr3jSgLOInyqcBwA\&thl=uk\&sa=X\&ved=2ahUKEwjE796Ei MzmAhUrwMQBHYJkC8

7. Комунальна установа «Ізмаїльський архів». - Ф. 755. - Оп.1. - Спр. 98.

8. Суходолска К. Бъмгарите в неиздадените мемоари на Чайка-Чайковски (Садък паша) //Сборник за народни умотворения, наука и книжнина. София, 1894. - Кн. 10.

9. Стойчевъ И. Две знамена съ крестъ и полумесецъ. - София: Печатница на Военно-издателския фондъ, 1940. - 15 с.

10. Czajkowski M. Kozaczyzna w Turcyi: dzieło w trzech cześsciach. - Paryz : w Drukarni L. Martinet, 1857.

11. Яворницький Д. І. Історія запорозьких козаків. - Авів, 1990. - Т. 1. - С. 172.

\section{References:}

1. Czajkowski M. Kozaczyzna w Turcyi: dzieło w trzech częściach.- Paryz : w Drukarni L. Martinet, 1857. [in Polish].

2. Bachyns'ka O. Kozatstvo v "pislyakozats'ku dobu" ukrayins'koyi istoriyi (kinets' XVIII - XIX st.) /Olena Bachyns'ka. - Odesa: "Astroprynt", 2009. - 256 s. [in Ukrainian].

3. Bachyns'ka O.A. Dunays'ke kozats'ke viys'ko. 1828-1868 rr. (Do 170-richchya zasnuvannya). - Odesa: Astroprynt, 1998. - 232 s. [in Ukrainian]. 
4. Bachyns'ka O.A. Kozats'ke porubizhzhya u Velykiy politytsi mizh dvoma rosiys'ko-turets'kymy viynamy pershoyi tretyny XIX st.// Chornomors'ka mynuvshyna. Zapysky Viddilu istoriyi kozatstva na Pivdni Ukrayiny Naukovodoslidnoho instytutu kozatstva Instytutu istoriyi Ukrayiny NAN Ukrayiny: Zb. nauk. pr. - Odesa, 2018. - Vyp. 13. - S. 161-194. [in Ukrainian].

5. Dashkevych Ya. Prapory zaduys'kykh zaporozhtsiv (XVIII - XIX st.) //Znak. Chyslo 46, hruden' 2008. - S. 8-11. [in Ukrainian].

6. Sukhodolska K. B"lgarite $\mathrm{v}$ neizdadenite memoari na CHayka-CHaykovski (Sad"k pasha) //Sbornik za narodni umotvoreniya, nauka i knizhnina. - Sofiya, 1894. - Kn.10. [in Bulgarian].

7. Stoychev" I. Dve znamena s" krest" i polumesets". - Sofiya: Pechatnitsa na Voyenno-izdatelskiya fond", 1940. - 15 c. [in Bulgarian].

8. Yavornyts'kyy D. Istoriya zaporoz'kykh kozakiv. - Lviv, 1990. - T. 1. [in Ukrainian].

9. The State Archives of Odessa region. - F. 1. - Op. 214. - Spr. 11 (1825).

10. Public utility service Izmail archive (pus Izmail archive). - F. 755. - Op. 1. Spr.98.

11. Kantemir D. Opisaniye Moldavii: faksimile, latinskiy tekst, russkiy perevod Sturdzovskogo spiska. - SPb., 2011. [in Russian].

Бачинская Елена

ORCID: https://orcid.org/0000-0003-0496-5742 Доктор исторических наук, профессор, зав. кафедрой истории Украины Одесский национальный университет имени И.И. Мечникова, УА. Дворянская, 2, 65082, Одесса, Украина Olena_an@ukr.net

\section{Особенности институализаиии задунайских запорожиев и дунайских казаков по материалам сфрагистики, вексиллологии и пространственной локализации}

Важность символов власти, а именно: печати, полотнища или фрлаги, трудно переоценить. Их появление в той или иной форме свидетельствует о легализаиии определенной организации, учреждения, общества. Именно поэтому предложенная статья посвящена особенностям этого проиесса, процесса институализации в задунайских запорожиев и дунайских казаков в последней четверти XVIII - XIX вв.

Предложено рассмотреть эти проиессы, используя материалы сфрагистики, вексиллологии и пространственную локализацию, в частности печати, полотнища, флаги и тому подобное. Установлено, что появление этих символов власти, во-первых, отражала легализаиию и вписывания в определенную государственную систему соответствующую казацкую институиию - Сечь или войско. Во-вторых, в каждой из этих институиий на печатях и знаменах отражались символь соответствующего государства Османской или Российской империи, иногда с апеляцией $\kappa$ казаикому прошлому. Например, сочетание символов ислама с христианскими на флагах задунайцев, или предоставления насеки (булавы) дунайским казакам в Poccuu.

Ключевые слова: Задунайская Сечь, Дунайское казачье войско, печать, бунчук, фрлаг, с. Катырлез, с. Дунавещь, станииа. 
Додатки:

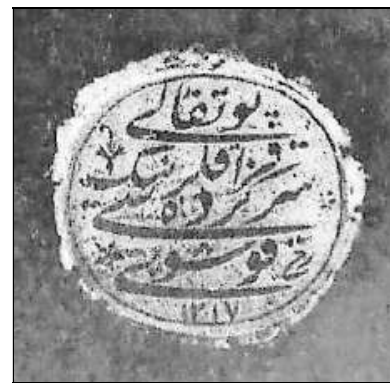

Puc. 1. Запорозъких козаків головний кошовий

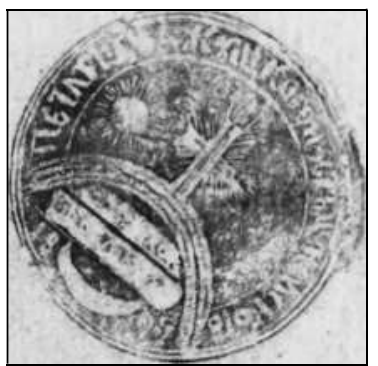

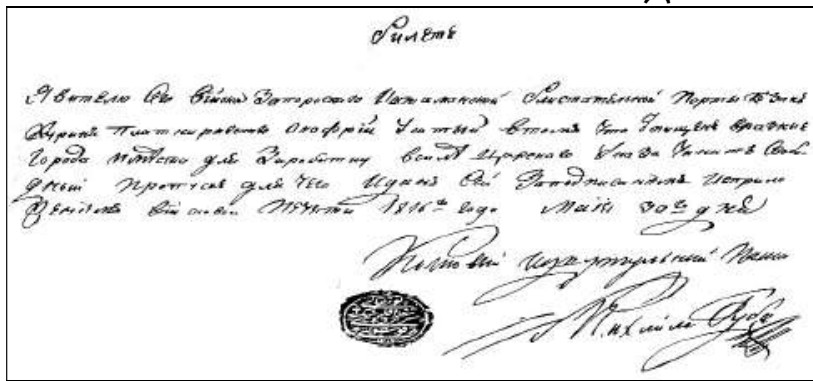

Рис. 2. Білет- пропуск на заробітки Онуррія Усатого козака Платнірівсъкого куреня Задунайсъкої Січі.1816 p. Підписаний кошовим двутульним пашею М. Губою

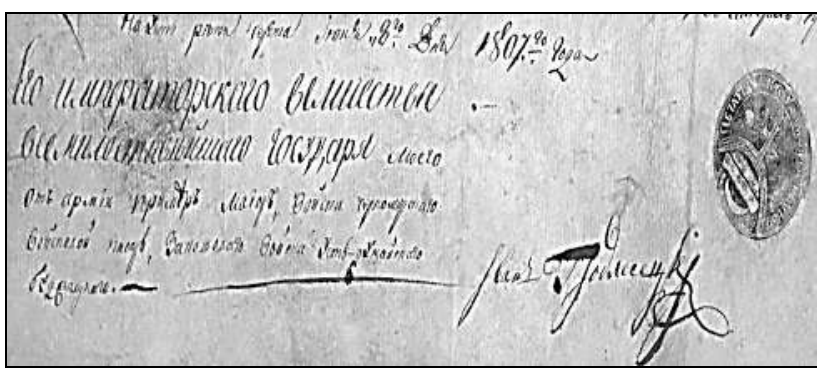

Рис. З Печатка Усть-Дунайсъкого Буджацъкого війсъка.1807 p.

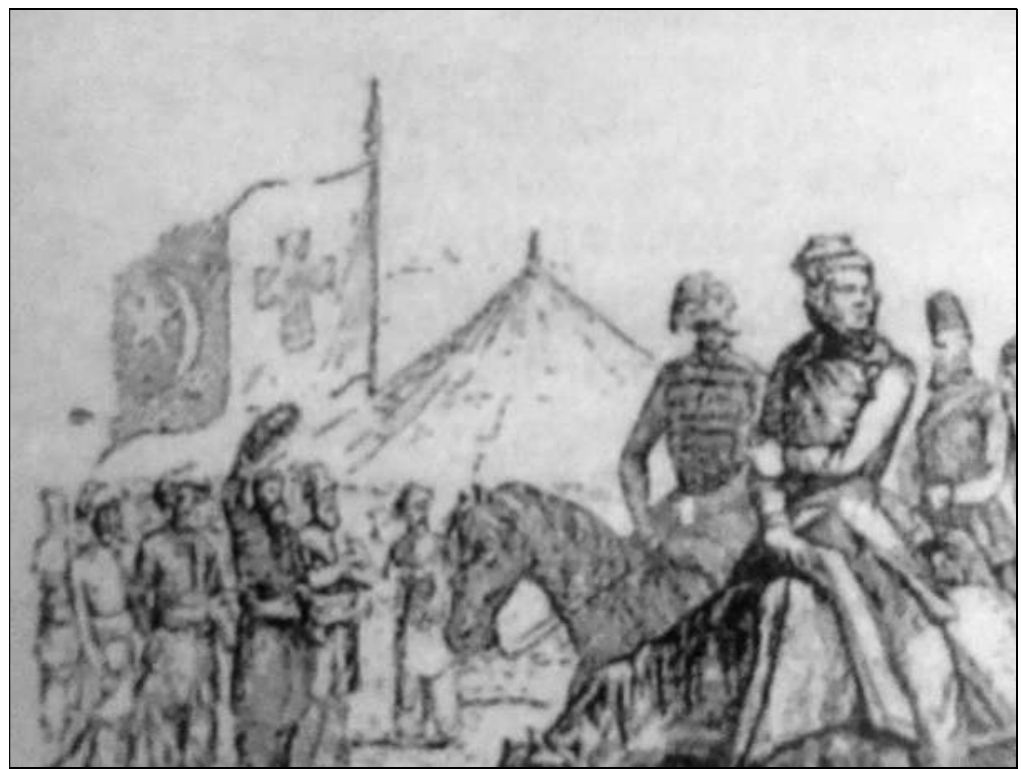

Рис. 4. Прапор задунайсъких козаків полку М. Чайковсъкого. 1853 p. 


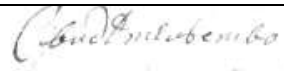

$2 /$

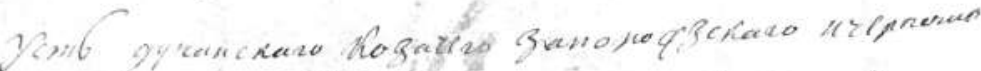

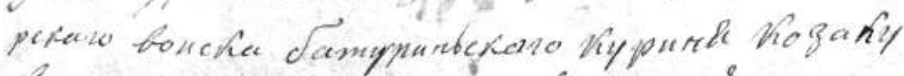

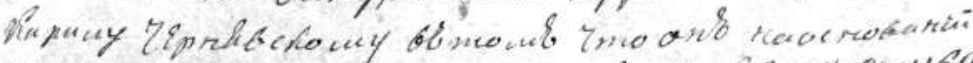

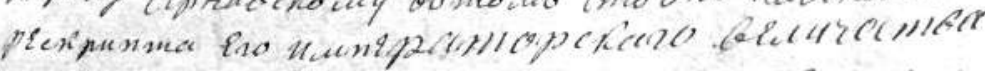

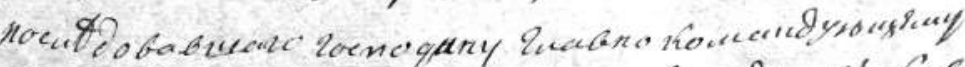

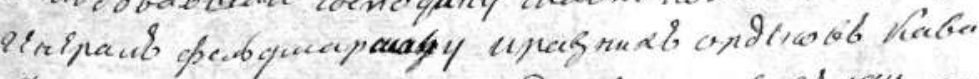

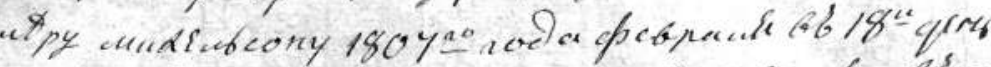

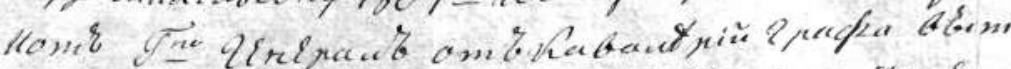

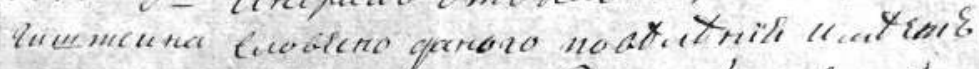

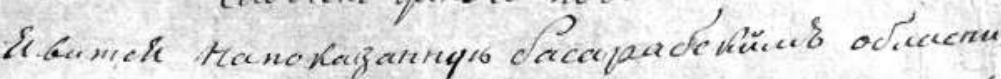

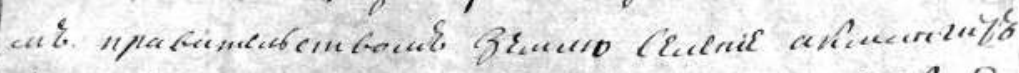

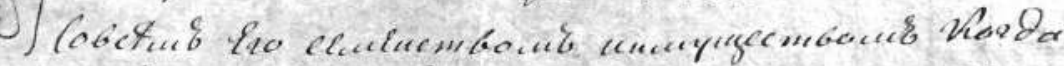

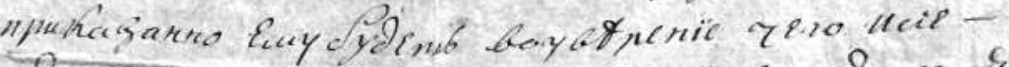

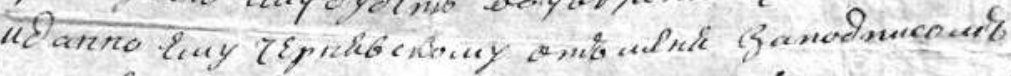

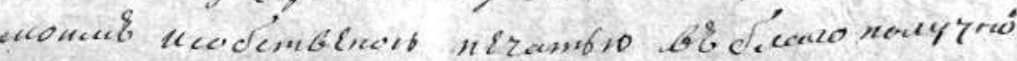

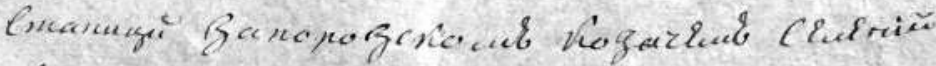

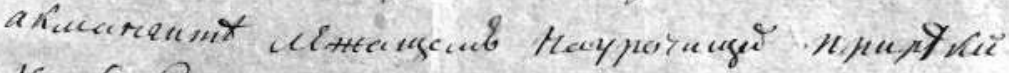

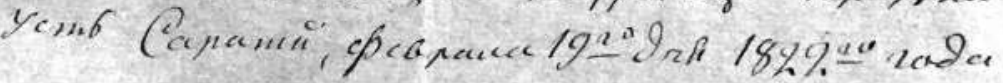

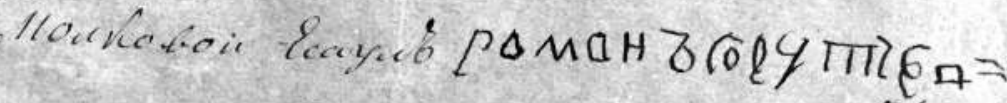

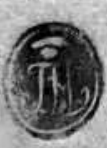

$=c k i \breve{u}$

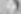

Befogenginon

Trrecant Viy

Рис. 5. Печатка представника задунайців осавула Романа Согутиевсъкого. 1822 р. 


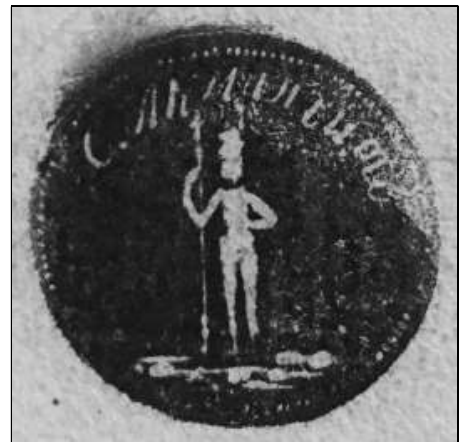

Рис. 6. Печатка козаків c. Акмангіт. 1828 p.

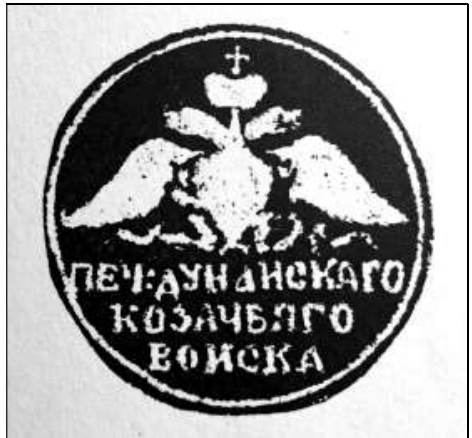

Рис. 7. Печатка Дунайсъкого козацъкого війсъка. $1851 \mathrm{p}$.

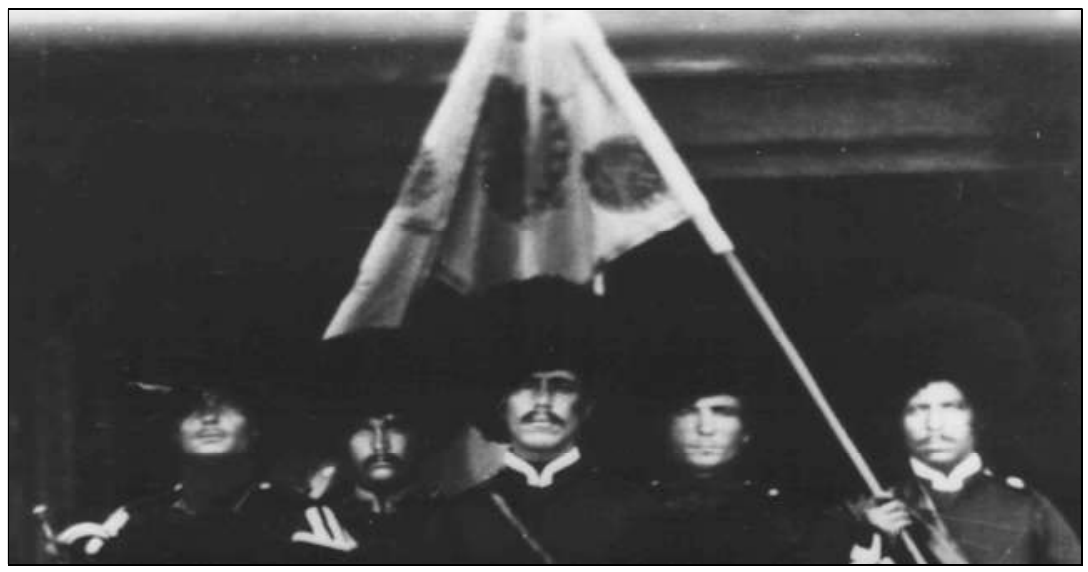

Рис. 8 Козаки Дунайсъкого козацъкого війсъка з прапором.1856 p.

Отримано: 10.12.2019p. 